\title{
Women as Agents of Peace and Social Development in the South- Eastern Nigeria
}

\author{
Church-Hill Amadi-Nche ${ }^{1 *}$ Ibiene Opuine Anga-Nyanabo ${ }^{2}$ \\ 1. Crowther Graduate Theological Seminary, P.M.B 2233, Abeokuta, Ogun State \\ 2. Crowther Graduate Theological Seminary, P.M.B 2233, Abeokuta, Ogun State \\ * camadinche@gmail.com*opunyanabo@gmail.com
}

\begin{abstract}
Contemporary gender discourse on African socio-cultural and religious issues in the past decades tend to give more accolades to the masculine rather than the feminine genders. Consequently, the male is viewed from the positive, objective, strong, intellective, dominant and determined perspective while the female is regarded as weak, passive, emotional, intuitive, childish, dependent and evil. These negative perceptions of most African male as regards to women has led to the present day women struggles for equal rights and opportunities in the educational, political, social, cultural, economic and even religious spheres. How true is the perceptions of most African male as regards to women? Are there no roles played by women in the traditional African society which distinguishes them as strong, objective and intellective? How have women contributed to the initiation of peace and peace building in the traditional African society especially in the South-Eastern Nigeria? This is the thrust of this paper. The paper examines the role of women as agents of peace and social development in the African traditional society with reference to the South-Eastern Nigeria. Having employed the descriptive analysis, the paper argued that before, during and after the colonial era, women have been agents of peace and social development in the African traditional society particularly in South-Eastern Nigeria. This is achieved through a female association known as Omurinya/Umuada. The paper strongly recommends that rather than marginalize, discriminate or oppress women based on their gender, there should be equal treatment of both men and women in all spheres of human endeavour. Key Words: Women, Peace, Patriarchy, Gender, Omurinya/Umuada

DOI: $10.7176 / \mathrm{JAAS} / 69-05$

Publication date:November $30^{\text {th }} 2020$
\end{abstract}

\section{Introduction}

The African society is patriarchal in nature. Thus men are always given the pride of place in the socio-cultural, educational, political, economic and religious spheres while the women are often times relegated to the background. Though, women perform indispensable roles in the traditional African society such as giving birth to children, providing the foremost education for their children, transmiting the cultural values, norms and traditions of the society to their children and adocating for peace in the traditional society. However, these roles remain largely unrecognized or at best given a nodding attention in a patriarchal society such as Africa, Nigeria inclusive. Patriarchy is simply defined as a social system in which the father or eldest male of the family is head of the household, having authority over women, children and servants. Patriarchy also refers to a system of government by males, and to the dominance of men in social or cultural systems. Patriarchy allows the husband to exercise power over his wife in that the wife rights and freedom is only within the context of the authority of the husband (Ogunkunle 2006). The aftermath of patriarchy is the present day women struggles for equal right and opportunity in all spheres of human endeavour both in the African continent and the global community.

In view of the above remarks, this paper seeks to examine the role performed by women in the traditional African society as agents of peace and social development with respect to women in the south-eastern Nigeria. How do women in the south-eastern geo-political zone in Nigeria foster and contribute to the initiation of peace and peace building in the traditional African society? What are the mediums through which women in the south-eastern Nigeria employ to achieve their peace initiative and project? This is the focus of this paper. Worthy of note is the fact that there are six geo-political zones in Nigeria which are the North-Central, North-East, North-West, SouthWest, South-East and South-South. The south-east as one of the six geo-political zones in Nigeria comprises of five states namely Abia, Anambra, Ebonyi, Enugu, and Imo state. The south-east is the home of the Igbo speaking tribe of Nigeria having common identity, cultural values, norms and traditions. The south-east is the scope of this paper since their cultural heritage is the same. The region is largely agrarian. This is because they have good cultivating soil and waters for fishing. Moreover, the region is receptive to the three major recognized religions in the Nigerian constitution namely Christianity, Islam and African Traditional Religion. 


\section{Gender Disparity in South-Eastern Nigeria}

As opined above, the African society is a patriarchal society. Hence, most cultures, customs and traditions in the African traditional society are inimical to women. Consequently, the south-eastern Nigeria a sub-region in the African society practice patriarchal system of government. In view of the above, authority in the family lies solely in the hand of the father, son or brother with the exclusion of the wife, mother or sister. In a typical south-eastern home, the father as the head of the family is called Mazi (father). After the father comes the first son known as Okpara. The Okpara, is followed by the Orlu who is the second son. On the female side, the woman is known as Nne for mother, Ada for the first daughter and then Orlu for the second daughter. In south-eastern communities, in the absence of the father, the first son (Okpara) takes over the affairs of the home. He enacts and enforces laws just like the father would have done. Ogbuehi (2019) remarks that "the republician system of government in which the first son represent the family has no room for women in decision making, particularly, in making policies or decisions that affects women. He notes that women are not part of village assembly which is made up of male adults alone. He further asserts that women were not members of council of elders irrespective of their age and expertise". This mediun is used to create myths, tradition and ritual which is aimed at oppressing and dominating women. Other inhuman treatment melted south-eastern women based on their gender are bitter widowhood experience, female genital mutilation, wife battering, denial of the right of inheritance among others. Although bitter widowhood experience is gradually phasing off but not yet completely. The practice is carried out to ascertain the wife/ wives innocence in the death of their husband. The surviving spouse(s) usually goes through psychological trauma for the loss of a husband. The moment the announcement of a deceased husband is made, all sorts of accusations are leveled on the woman/ women (in case of polygamy) by the family of the late husband. Various kinds of ritual oaths are compulsorily heaped on the widow to observe while in the case of the widower he goes scot-free. This attitude confirms Lasebikan (2001) observation that "in Africa, the widow is oppressed, suppressed, afflicted, neglected and insulted". In Igbo customs and tradition, upon the death of a wife, the widower can decide to remarry again immediately without any caution after burial.similarly, the widower can leave his house and travel to any place he likes with or without the mourning black cloth but that cannot be done by the widow. Despite gender disparity of women in the south-eastern Nigeria, the women are still indispensable for societal development. Amolo (2019) opines that "in most societies, women assume five key roles: mother, producer, home-manager, community organizer and socio-cultural and political activist". Oluwawunsi and Ogunbisi (2019) affirms this when they state that "the three most significant roles performed by women in the African traditional society are first, the procreative role; second, the domicillary; and third indirect political influence". Nmah (2003) on his part avers that "women fetch water and firewood for domestic purposes and also carry the produce of their farm usually many kilometers away from their homestead to sell at the market".

Akintunde (2003) corroborating the above views adds that: women are gifted with great potentials as organizers, mobilizers and motivators. They encourage children to relate positively with each other and to take responsibility at the family, local and national levels. While some women perform the roles of careerists, wives, mothers, counselors and teachers in the contemporary society. They are vested with the responsibility of transmitting the cultures and tradtions of the land to their progenies.whereas some women perform the role of diviners, musicians, healers, priestesses in the African traditional religion, others acts as preachers, evangelist and choriesters in contemporary christianity.

Women in the south-eastern Nigeria maximize their potential to minimize the effects of violence by actively making frantic efforts to end wars and acting as peace agents. This is achieved through an association known as the Umuada. This is the main thrust of the next sub-theme.

\section{Umuada and Peace Building in South-Eastern Nigeria}

Peace is derived from the Latin word Pax. Peace is generally defined as the absence of war, fear, conflict, anxiety, suffering and violence and about peaceful coexistence. It is primarily concerned with creating and maintaining a just order in society and the resolution of conflict by non-violent means. Peace is also the existence of justice and equality that guarantees provision of life are met. Peace further entails the eradication of violence, oppression, greed and environmental destruction by positive intervention of conflict. Like the concept 'religion', there is no one universally accepted definition for peace hence, peace is conceptualized from the philosophical, sociological and political point of view. The word peace suggests well-being, harmony, prosperity, health, long life, security and lack of violence and misfortune. Ogbuehi (2019) remarks that "peace is a vital component of national growth and development. Without peace it is difficult for progress to be achieved". In other words, peace enhances sociocultural and religious development. Amolo (2019) on her part classifies peace into two namely: internal and 
external peace. She remarks that "internal peace is a state of calm, serenity and tranquility of mind that arise due to having no sufferings or mental disturbances such as worry, anxiety, greed, desire, hatred, ill-will, delusion and or other defilments. She describes external peace as that which occurs in society, nations and the world and it is a state of peaceful and happy co-existence of people as well as nature". Citing Ghali Boutrous the former united Secretary-General, Amolo (2019) further avers that peacebuilding involves

Action to identify and support structures which will tend to strengthen and solidify peace in order to avoid a relapse into conflict...rebuilding the institutions and infrastructures of nations torn by civil war and strife and tackling the deepest causes of conflict; economic despair, social injustice and political oppression.

She also notes that peacebuilding comprises of joint work to deal with fundamental economic, social, cultural and humanitarian issues. The process involves the formation of programs, policies and associated efforts to restore stability and effectivenes of social, political and economic institutions and structures in the wake of war or mayhem. Before the advent of the colonial in Africa, women had been a veritable instrument in sustaining and building peace in the traditional African society. Women maintain peace in their families. They balance the men's temperament and the children's unruly behavior. They discipline their children, but they do not go to the extreme as some men sometimes do. The south-eastern Nigeria women achieve their peace project and peace initiative basically through a female association known as the Omurinya or Umuada. Okoro (2010) describes the Umuada as "the collectivity of all the daughters of a particular clan, village, town, or state whether old, young, single, married, separated or divorced". Amolo (2019) remarks that "Umuada is a compound collective noun from umu (children) and ada (daughter); umu is a generic term that conveys the sense of many. Although, the term ada is used in reference to the eldest daughter of a family, ada generally means a female child". She further states that "in essence, all daughters of a particular village, clan, or town and whether old or young; single or married; divorced or separated, all enjoy equal rights within the group". Umuada simply means the daughters of a common male ancestor or daughters of the soil. It is an "absolute right of every daughter of a particular place, without exception whatsoever, to belong to the Omurinya or Umuada, an association of the native daughters" (Amolo 2019). The Omurinya or Umuada play lots of role in the society as leaders, peacebuilders, developers, economist and mothers. Their role as peacebuilders is so prominent that every family, community or clan that has any irresolvable conflict invites the Omurinya or Umuada to intervene and in most cases they help to bring about peace. The roles of the Omurinya or Umuada could be seen in the way they handle the following issues in the community: The settlement of disputes among fellow women in the community, infidelity issues involving offending wives, assault on a wife by a husband, assault or physical attack of a wife on her mother-in-law, conflicts involving physical fighting between parties (Amolo 2019). Corroborating this view, Onuoha (1999) writes that the Umuada association ensures that peace and justice are maintained in the traditional community. The Umuada settle disputes that arise between husbands and their wives, they also promote the stability of their community. The Umuada ensure that sanity, fair play, peace and justice reign in their natal homes. An interesting remark about the Umuada is that they are never partial in their judgment. Nmah (2003) writes that "the Umuada exercise moral powers that no one questions within the community". When they rule on an issue their decision is final and must be obeyed by all. Nwoye (2015) asserts that "the Umuada exercise remarkable power in their natal homes as peacebuilders, more so than in their marital home because of the immunity they enjoy as authochthons, or daughters of the soil, in constrast to wives, who are viewed as outsiders or foreigners to their clans and communities by vitue of being married to male members". Ogbuehi (2019) remarks that it was the Umuada that resolved the aged long land dispute between Umunebo and Umuokuzu in Owerri local Government Area. Similarly, the Umuada of Aguleri and Umuleri communities in Anambra state were instrumental to the restoration of peace between the warring commuities which clamed lots of lives. Also, the women of Nkanu East Local Government Area of Enugu State played prominent role in resolving the conflict that engulfed the region. Afigbo A.E. (1981) maintains that the Umuada resolve conflict between warring communities and villages by carrying green leaves or folded palm fronds to the battle ground which symbolizes peace. They march to the battle field, singing songs that portray the dangers of war and the need for peace. The peaceful songs and mood of the women usually inspire the emotions of the parties to initiate peace. In case the intervention of women is disregarded, they stand the risk of harming their own daughters which is a taboo to Ala the earth goddess.

\section{Women in Old Testament}

The male hierarchical structure of the Old Testament did not deter God from calling some women to high and reputable office of being his mouthpiece. Osiorhoroja (2010) opines that there are two classes of women in the Old Testament, the prophetess and the non-prophetess. Both groups were prominent in the life of the nation of Israel. Among women who were famous for their faith in the Old testament are Miriam the sister of Moses, who 
led a choral dance in celebration of Israel's deliverance from Egypt (Exodus 15:20); Deborah the brave wife of Lapidoth "a mother in Israel" who was consulted as an inter-tribal judge (Judges 4:4-7); Oguntoye (2001) remarks that Deborah who acted in the capacity of a judge in Israel sitting under the palm tree between Ramah and Bethel in the mountains of Ephraim still served as a wife to Lapidoth. She functioned simultaneously in the trio-capacities. Such rare combination of quality climaxed when she, Deborah, under prophetic influence invited Barak the Israelites general to go to battle against Sisera. At the refusal of Barak to go to battle, she wields her power and authority to influence the fearful general to go to battle with him to prove that God can make use of any available vessel not excluding women. Sisera who fled before the army of Israel came to the dwelling of nomad's whose matriarch was Jael. Jael as a woman was used by God to drive a nail through Sisera's head. She thus became the first woman whom God decided to honour by delivering into her hands an army general (Isiorhoroja 2010). Huldah the woman who inspired the religious reformation of King Josiah (11 Kings 22:14-20; 11 Chronicles 34:22-28), was not deterred by the patriarchal nature of her society. Thus, she faithfully delivered the words given her by the Lord concerning King Josiah (145). King Josiah consulted her so as to ascertain the correctness of the scroll. Her prophecy gave King Josiah greater courage to put into action the law. Noadiah the prophetess who opposed Nehemiah is equally worthy of mention (Nehemiah 6:14). Other women who distinguished themselves include the women in Exodus 35:22-26 in connection with the building of the tabernacle. Some women came with men. Thus, they took part in the building of the sanctuary for God (Campbell 1991). Esther the Queen of Susa, through her devotion saved her people from destruction. Ruth was remembered for her dedication and love to her mother-inlaw. Hannah was notable for her prayer at Shiloh. In addition to the above named prophetess and women, many other faithful women were found in the Old Testament. They include Sarah, Rebecca, Naomi, Abigail, the woman of Shunem.

\section{Women in New Testament}

Svetlana (2013) underscores that "record from the New Testament reveals that Jesus and Paul valued women and treated them with respect and dignity". The four gospels of the New Testament contain vital information on the relationship of Jesus to women and portray the involvement of women in the life and ministry of Jesus. Women were key witnesses to the events of Jesus' life. They played prominent roles in the events surrounding his crucifixion and resurrection. They were willing to risk their lives for Jesus, remaining at the cross and visiting the tomb while the male disciples had fled (Akintunde 2005). (John 19:25; Mark 15:47; Matthew 26:57). Mahoney (1993) adds that the account of Matthew, Mark and John depicts women as the first to see Jesus after his resurrection (Matthew, 28:1-18; Mark, 1:1-19; John, 20:1-19); the first at the empty tomb and the first to proclaim the message of his resurrection. "In the gospel's, Jesus' attitude and behaviour towards women were in contrast to the norms of his time. Jesus healed women and allowed them touch him and also follow him. He spoke without restraint to them. He related to them primarily as humans being rather than as sexual beings" (Akintunde 2005). Jesus accepted women who were neglected and rejected within his society as persons of worth (John 8:1-2), Mahoney (1993) underscores that the first persons to receive Paul and Silas in Macedonia were women (Acts 16:13). Lydia, the first European convert exhibited hospitality to the apostles (Acts 16;11-15). She was wealthy, having a home large enough to accommodate her own family as well as guest rooms for Paul and Silas. In Thessalonica, many leading Greek women believed the preaching of Paul and Silas (Act 17:4, 12) to the annoyance of the Jews. Philip had four unmarried daughters who prophesized (Acts 21:8,9). They were God spokespersons. The account of Acts 12:12 recounts that after Herod had murdered James the Brother of John on account of the gospel, he proceeded to arrest Peter because it pleased the Jews who were antagonistic to the preaching of Christ. In response, a prayer meeting for Peter's deliverance was held in the house of a woman, Mary the mother of John Mark at a risk of incurring the wrath of the pompous and wicked Herod the King. Other women notable in the New Testament include the women of Berea who studied the scriptures diligently (Acts 17:10-17), Eunice and Lois mother and grandmother respectively of Timothy (1Timothy 1:5). The powerful preacher, Apollos had Priscilla's help to him explain the way of God more adequately (Act 18:24-27). Phoebe, a deaconess of the church at Cenchrae is worth mentioning, Paul described her as being a great help to many (Romans 16:2). From the foregoing, it is evident that women were never silent but functioned effectively in their various capacities. In the Old Testament times as in the New Testament women were not seem as merely observers but participants in different fields of endeavour.

\section{Women in African context}

From the foregoing, women in the Africa context have been discovered to be veritable instruments to be reckoned with. Rather than be an object of ridicule, to be silenced, seen and not heard, women hitherto have proven their mettle. So many women have made land mark achievements even where their male counterparts have failed. For instance, women like Professor Condoleezza Rice rose in her career to be the $66^{\text {th }}$ United States Secretary of State. She was the second person to hold the office in the administration of President George W. Bush. Ellen Johnson 
Sirleaf is a Liberian politician who served as the $24^{\text {th }}$ President of Liberia from 2006 to 2008. She was the first female elected head of state in Africa. Olufunmilayo Ransome Kuti the wife of the renowned reverend Israel Ransome Kuti is instrumental for organizing a lot of campaigns against colonial rule. Professor Dora Akunyili as former Director General of NAFDAC (National Agency for Food and Drugs Administration Control proved her mettle. It was during her tenure as Director General that most Nigerians knew that such an agency was in existence. She was a strong voice in the globe that battled fake drugs and created the much needed awareness on the negative effects of fake drugs. Similarly, Professor Grace Alele-Williams made history as the first female Vice-Chancellor of the University of Benin. Virginia Etiaba was once an acting Governor of Anambra State when Chris Ngige was impeached. With this, she became the first female Governor Nigeria has ever produced. She no doubt played and fulfilled that role in a way that was expected of her. She broke the jinx of having all male affairs governor in Nigeria. Mercy Amba Oduyoye a Ghanaian Methodist Theologian is known for her effort in African women's theology. In spite of the misconception and the various views or options by some persons and institutions in the modern time and the adverse effect of globalization on women, there are a lot of women who have achieved no less mean feats globally and are still making waves. In addition to the aforementioned, women in the modern Africa context are described as educators, mothers, musicians and peace agents. As educators, women educate their young ones in the richness and diversity of the community cultures, customs, traditions, moral and general etiquette of the society. They primarily had the responsibility for the upbringing of the children. Children, when very young, remained with their mothers, who took after both boys and girls until they reach a given age. In other to actualize the purpose of bringing up morally sound children, strict rules to be compiled with on how to dress, speak, eat, walk and sit especially for the girls were made (Okoro 2010).

\section{Recommendations}

The paper recommends that owing to the enormous role south-eastern women perform in sustaining peace in their natal homes, women like their male counterpart should be given a pride of place in the socio-economic, political and religious spheres.

Besides, for the purpose of equity in all spheres of life, south-eastern women, like their male counterparts, should no longer be discriminated in all societal affairs. They should be allowed to express their divinely endowed potentials. The thought that women are to be seen and not heard must be jettisoned for the purpose of equity women must be given a voice.

The various ill treatments on south-eastern women, and women in general as captured in this paper bordering on sexual abuses, harassments, forced and early marriages, divorce, bitter widowhood experience, inequality in education, religious marginalization, political suppression and imbalance in employment on account of the gender should be checked by government at the National, State and local level and even traditional society and ensure that perpetrators of such abuses are brought to book.

The role of south-eastern women be it in the family, society or church should be encouraged at all levels rather than being discriminated based on their gender.

\section{Conclusion}

Though the African society is patriarchal in nature and views women as lesser beings that should remain docile, be exploited, suppressed, abused and oppressed in the socio-cultural, political, educational and religious spheres of human existence. It is important to note that women in Africa and women generally are worth more than the patriarchal conception and perception. This is clearly evident in this paper using the activities and roles of the south-eastern Nigerian women in fostering peace and social development in their natal lands through the formidable association of the Umuada. Having considered some areas women are discriminated against based on their gender and the irreplaceable roles of women in the Igbo speaking region of Nigeria, the paper reveals that the south-eastern women have been and are still vanguards of peace in the traditional African society. States and communities in the south-eastern part of Nigeria as opined in this paper have benefited and are still benefiting from the inestimable roles women play in maintaining and sustaining peace in their natal homes through the female association called Omurinya or Umuada. The south-eastern women role as peace agents in their natal homes is also extended to their marital homes. Though a patriarchal society, women in the south-eastern Nigeria are peculiar in the advancement of peace and peace building.

\section{Bibliography}

Afigbo, A.E. Ropes of Sand. (1981). Nsukka: University of Nigeria Press. 
Akintunde, D.O. (2003). "The Impact of Women on Nigerian Society" S.O. S.O. Abogunrin et al ed. Biblical Studies and Women Issues in Africa. Ibadan: Philarem Corporate printers, 171-197.

--- (2005). "Decolonizing Biblical Studies in Nigeria: Women perspective" S.O. Abogunrin et al ed Decolonization of Biblical Interpretationl in Africa. Ibadan: M. Alofe Nig. Enterprise, 95-120.

Amolo, Hope. (2019). "The Role of Women towards Peace and Justice: Implications for Security of the Church and Nigerian State" Nigeria Journal of Christian Studies Vol. 3, No. 3, 240-270.

Campbell R. K. (1991). Women Role According to Scripture. Sunbury Pennsylvania: Believer's Bookshelf.

Isiorhoroja, Uyovwieyovwe O. (2010). Exegesis of 1 Corinthians 14:33-36: The Silence of Women in The Church and the Pentecostal Practices in Warri Urban. An Unpublished M.A. Thesis, submitted to the department of Religious Studies and Philosophy, Delta State University Abaraka.

Lasebikan, Esther. (2001). "African Cultures and the Quest for Women's Rights A General Overview" African Cultures and the Quest for Women's Rights. Ed. D.O. Akintunde. Ibadan: Oluseyi Press, pp. 9-18.

Mahoney Raph. (1993). Women as Ministers and Leaders in Acts Vol. 27. California.

Nmah, Patrick Enoch. (2003). Women's Rights in Igbo Land A Christian Reappraisal. Aba: $\quad$ Soul Winner Pub.

Nwoye, M.A.C. (2015). "Role of Women in Peace Building and Conflict Resolution in African Traditional Societies: A Selective Review" (Online) Available http://www.afrikaworld.net/afrel/chinwenwoye.htm (February 2, 2015).

Ogbuehi, Friday Ifeanyi. (2019). "The role of women in fostering peace and justice in Nigeria" Nigeria Journal of Christian Studies Vol. 3, No. 3, 46-66.

Ogunkunle, Caleb O. (2006). "Biblical Injunction on Marriage and Sexual Union in the Context of Christian Marriage in Nigeria" et al ed S.O Abogunrin. Biblical View of Sex and Sexuality from African Perspective. Ibadan: M. Alofe Nig. Enterprise, 48- 60.

Oguntoye Paul Alabi. (2001). "Prophetess in Religious life in Israel” S. O. Abogunrim et al ed. Biblical Studies and Women Issues in Africa. Ibadan: Philaren Corporate printers, 14-36

Okoro, K.N. (2010). "Women and Peace Initiative in Igbo Traditional Society; A Viable Option for Peace Building in Modern Africa" International Journal of Humanities Vol. 2, No.2, 20-33.

Oluwawunsi, O. Adekola and Ogunbisi, F. Abiodun. (2019). "Role of women towards peace and justice: Implications for security of the church and Nigeria state" Nigeria Journal of Christian Studies Vol. 3, No. 3,104-119.

Onuoha A.U. (1999). Studies in Igbo Religion and Culture. Aba: Vincent International Pub.

Svetlana Renee Papazov. (2013). The Place of Women in the Graeco-Roman World. (Online) Available http://www.bible.ovc.edu./terry/dissertation/1_3textbas.htm (September 4th, 2013). 